\title{
Analysis of Government Expenditure and Sectoral Employment in the Post-apartheid South Africa:
} Application of ARDL Model

\author{
${ }^{1}$ Thomas Habanabakize, ${ }^{2}$ Paul-Francois Muzindutsi \\ ${ }^{1}$ North-West University, Vaal Campus, Vanderbijlpark, South Africa \\ ${ }^{2}$ University of KwaZulu-Natal, Pietermaritzburg campus, South Africa \\ *tomhaban12@gmail.com, muzindutsip@nwu.ac.za
}

\begin{abstract}
The current study has been designed to analyse the interactions between real government spending and job creation in South Africa focusing on five major economic sectors, namely construction, financial, manufacturing, mining, and retail sectors. The main objective of the study was to determine how job creation in different economic sectors responds to changes in real government spending. To achieve this objective, the study used five different autoregressive distributed lag (ARDL) models to analyse the long-run and shot-run relationships between government spending and employment rate in each of the aforementioned five economic sectors. The sample period consisted of quarterly observations starting from the first quarter of 1994 to last quarter of 2015. The study found a long-run relationship between government spending and job creation in the mining sector but there was no evidence of long-run relationships between government spending and jobs creation in construction, financial, manufacturing, and retail sectors. The short-run analysis showed that government spending could create jobs in all five sectors. This paper concluded that increasing government spending can only create short-term jobs but does not create lasting jobs in most sectors, except the mining sector. To increase the number of durable jobs, the South African government should therefore increase spending on mining sector.
\end{abstract}

Keywords: $A R D L$ model, employment, job creation, government spending, South Africa

\section{Introduction}

Unemployment remains a persistent serious challenge for many countries and it negatively affects economic growth and social wellbeing. As in other developing countries, unemployment in South Africa is one of the economic growth barriers and a strain to social wellbeing. South Africa's unemployment rate faced a shortfall and employment rate increased by one percent in 2015 (StatsSA, 2015). This decline in the unemployment rate was a result of improved job creation in some South African economic sectors (StatsSA, 2015). Despite this decline in unemployment rate, sectors such as transport, utilities and finance experienced a decline in employment rate (StatsSA, 2015). Nevertheless, the growing unemployment rate remains a crucial concern for South African macroeconomic authorities and policy-makers. Among various strategies used to boost job creation, fiscal policy is seen as one of the major tools that can be used to deal with unemployment. However, economists tend to have different views on how fiscal policy can be implemented in order to promote economic growth and employment creation (Edelberg et al., 2002). One of the fiscal policy components that can assist with addressing unemployment is government spending, since an inverse relationship exists between unemployment and total government expenditure (Farmer, 2010). According to the South African Reserve Bank (2015), government spending refers to any amount spent by government in purchasing goods and services, investment or subsidies to stimulate growth and job creation within the economy. However, government alone is not able to create all employment; the private sector also plays an important role towards creating employment in the economy. Therefore, a combination of public and private sector would allow total government spending to be more effective and efficient (Kenyon, 1997).

The role of spending in the economy is explained by the new Keynesian model, which emphasises that government spending plays an important role towards employment growth. Within the new Keynesian model, individuals and firm's behaviour and decisions are grounded mostly on their expectations of how much the government would spend in an economy (Cogan et al., 2010). Though in some instances government spending might not be targeting job creation, each cent spent by government creates jobs indirectly (Roberts, 2010). Consequently, government spending creates jobs regardless of how spending is allocated. In contrast, Riedl (2008) argued that the theory insinuating that government spending stimulates economic growth and new jobs should be viewed as a myth because government does not have a stock of money from which it can take a portion for its spending. Rather, government has to tax or borrow out in 
order to spend on economic and social activities. As a result, the government's main task becomes resource redistribution instead of job creation. Nonetheless, this resource redistribution would eventually lead to job creation.

In the South African context, the increasing unemployment rate has progressively created a barrier to economic expansion. Unemployment is the root of many other challenges such as inequality, poverty, labour unrest and sluggish development (Kingdon \& Knight, 2004; Ferreira \& Rossouw, 2016). In trying to resolve the unemployment problem, South African government has introduced and implemented different strategies such as the Employment Tax Incentive (ETI) introduced in January 2014. The aim of the ETI was to allow companies and employers to hire more young job seekers (South African Revenue Services, 2016). According to African Economic Outlook (2015), the ETI has created more than 5600 jobs since its introduction. However, Ranchhod \& Finn (2016) found a negative effect of ETI on employment because it did not reduce the growing unemployment rate. Thus, the contribution of government spending and other government strategies on job creation seems to be ambiguous. This ambiguity of the relationship between government spending and job creation is the motivation behind this study. Thus, the main aim of this study is to analyse how government spending can enhance job creation within different economic sectors. More specifically, the objectives of this study are to compare short-run and long-run links between government expenditure and job creation in different economic sectors in South Africa and to identify the specific sectors that can boost job creation through government spending.

\section{Literature Review}

Government spending is one of the expansionary fiscal policies that drive firms and consumers' behaviours; it can boost production and increase consumption (Dornbusch et al., 2014).Government is able to employ different strategies through fiscal policy to increase the number of new jobs, depending on the country's current economic position (Meyer, 2014). Studies have been conducted to determine the relationship between job creation and government spending and their findings tend to differ depending on the study location (country) and/or the methodology employed by each study. Holden \& Sparrman (2016) analysed how government expenditure affects employment in 20 countries of the Organisation for Economic Cooperation and Development for the period of 27 years and found that an increase in government spending led to economic growth, which thereafter increased the level of employment. Habanabakize \& Muzindutsi (2015) also found that government spending has a long-run effect on job creation in South Africa. This confirms the inverse relation between government spending and unemployment rate. The more government spends, the lower the unemployment rate and the higher the number of new jobs created (Ramey, 2012).

Job creation is normally linked to economic growth. The economic growth results from various economic sectors' activities and those activities affect employment in different ways. Thus, a country's employment is an aggregate of job created from different economic sectors. Consequently, special attention is given to such economic sectors in order to determine how government should allocate the resources. To stimulate job creation, government must determine the right sector for resource allocation. Studies conducted on government spending and sectoral employment (Kenyon, 1997; Hassen, 2000; Levine, 2009; Cray et al., 2011; Leigh \& Neill, 2011; Estache et al., 2012; Maisonnave et al., 2013; Houseman, 2014) found that the infrastructure sector plays a key role in job creation compared to other economic sectors. Consequently, government spending in this sector is considered one of the better strategies to grow employment. This explains why the infrastructure sector was preferred by the South African National Development Plan as the generator of a higher number of new jobs (Mabugu, 2016). Government spending on infrastructure and subsidies to domestic firms tends to improve investments and create durable jobs (Girma et al., 2007; Beard et al., 2011; Boushey \& Ettlinger, 2011).

Beside the infrastructure sector, manufacturing, construction and mining contribute a large share towards employment growth (Dlamini, 2012; Maia, 2013; Muzindutsi \& Maepa, 2014). These three sectors have a common contribution to the economy, which is to create direct and indirect jobs. Direct contribution to job creation refers to the increase in hiring within the respected sectors, while indirect contribution involves stimulation of job creation in other sectors (Houseman, 2014; Atkinson et al., 2015). However, these sectors create jobs in different ways. For example, manufacturing employs people with advanced skills and academic 
qualifications, whilst construction and mining can hire a large number of semi-skilled and less qualified people (Saks, 2008; StatsSA, 2016). This means that increasing spending on construction and mining sectors can reduce unemployment in the semi-skilled population. Besides the aforementioned sectors, other sectors such as financial and retail contribute to economic growth and job creation, in particular through government spending. Different studies (Neumark et al., 2011; Wessels \& Ellis, 2012; International Labour Conference, 2015; OECD, 2015) found that business retail influence more on job creation. However, the contribution of small and medium retail enterprises differs from mature and large retail firms. The former can create and destroy jobs at the same time, while the latter creates and sustains jobs, even during economic crises. New firms are increasing firms attracting and hiring many people. However, lack of experience and less competitiveness can cause some of these new firms to fail and go bankrupt, resulting in massive job losses. Jobs created by large and mature firms are few, yet sustained, because these firms are competitive and they are less likely to be affected by changes in the business cycle (Kerr et al., 2014; OECD, 2015).

Without financial institutions, job creation in different economic sectors is almost impossible. Financial institutions play a major role in providing loans and funds to economic sectors. As with the manufacturing, mining and construction sectors, the financial sector hires employees and stimulates job creation within other sectors. Through financial institutions, the financial sector becomes a channel of money circulation (Asmundson, 2011). Therefore, government can increase jobs within various sectors via the financial sector. In addition, the financial sector plays another two important roles in the economy, namely job stimulation and job preservation in the private sector (Praveen, 2011; Botha, 2015). Most new firms and businesses need loans and financial support, which are provided mostly by financial institutions. Therefore, the financial sector indirectly creates jobs through other economic sectors. However, the financial sector is easily affected by economic crises; the negative effect of any crisis on the financial sector reduces employment, not only in the financial sector but also in other sectors that depend on financial services (International Labour Organization, 2009).

The aforementioned arguments support the hypothesis that an increase in government spending can create employment. However, findings of Afonso \& Sousa (2009) show that the contribution of government on job creation might be insignificant because government spending has little effect on GDP, which is the key to creating more jobs. What matters is not how much government spends, rather where government spends. If government spending is not targeting economic growth, the relationship between unemployment and government spending becomes negative. A study by Mahmood \& Khalid (2013) found that the Pakistan government spent more resources on the war and as result, unemployment increased. Furthermore, government spending on job creation is more effective during the sluggish economic conditions than when the economy is booming (Beard et al., 2011). Therefore, the outcome of government spending on job creation is subjected to the economic cycle. Whenever the country's economy is at a peak, the level of government spending on employment or job creation declines and the government has a possibility to support economic sectors' growth themselves; yet when economic growth is down, government has to increase its budget on job creation and unemployment support (Bertolis \& Hayes, 2014). When unemployment is high, as is the current case for South Africa, government spending should also be increased in order to support unemployed people by means of unemployment grants and to create employment (Loizides \& Vamvoukas, 2005). Although different studies asserted that government spending stimulates and indirectly creates jobs in the private sector, Ramey (2012) argued that government spending creates only direct employment (jobs in public sector). This is because job creation in the private sector results from spending from these sectors, yet government spending does not increase private spending, rather, in many cases, it causes a decline in private spending. However, this is not always the case as the government spending can boost private spending and job creation in some economic sectors (Tcherneva, 2008). Thus, establishing the link between sectorial employment and government spending in the South African context can shed more light on the topic.

\section{Data and Methodology}

This study used quarterly time series data from 1994 quarter 1 to 2015 quarter 4 . This sample period refers to the post-apartheid era, which started with the democratic government in 1994 (Padayachee \& Desai, 2011). Variables used include government spending and employment rate in five sectors, namely construction, manufacturing, financial, retail and mining. Real government spending is measured in billions of 
the local currency (Rand)and includes current payments, transfers and subsidies payments for final assets and interests paid on debts (SARB, 2015).Employment refers to the sum of formally created jobs in each sector and is measured by the number of jobs created (millions). The study used employment in construction sector (ECONS), employment in financial sector (EFIN), employment in manufacturing (EMAN), employment in mining sector (EMIN) as dependent variables whilst real government spending was used as independent variable. All variables were acquired from the South African Reserve Bank. Regarding methodology, the study adopted the autoregressive distributed lag model (ARDL) initially developed by Pesaran \& Shin (1996) and revised by Pesaran et al. in 2001. The ARDL model was chosen over Johansen \& Juselius (1990) cointegration because the latter estimates a long-run relationship within a system of equation, whilst ARDL simply uses a single and reduced form of equation (Pesaran \& Shin, 1995). The other benefit of using the ARDL model is that it does not require all variables to be integrated in the same order. Thus, the ARDL can be employed when all variables are stationary (I(0)), non-stationary (I(1)) or even when they are a mixture of I(0) and I(1) variables. Moreover, the use of the ARDL model allows the use of a different number of optimal lags for each variable. The ARDL formula employed to determine the relationship between government spending and employment is presented as follow:

$\Delta \mathrm{L} E M P_{t}=\propto_{0}+\sum_{j=1}^{k} \beta_{j} \Delta \mathrm{L} E M P_{t-j}+\sum_{j=1}^{k} \lambda_{j} \Delta G O V S_{t-j}+\varphi_{1} L E M P_{t-1}+\varphi_{2} G O V S_{t-1}+u_{t}$

Where $\triangle$ LEMPL denotes the change in natural logarithm of total sectoral employment at the time t; $\triangle$ LGOVS denotes the change in natural logarithm of total government spending at the time t. $\propto_{0}$ represents the intercept, $\mathrm{k}$ denotesthe number of lags, whilst $u_{t}$ designates white noise error term. $\beta_{j}$ and $\lambda_{j}$ indicate the short-term dynamics of the model, whereas $\varphi_{1}$ and $\varphi_{2}$ represent the long-run coefficients. Equation (1) was estimated for each of the five sectors; meaning that five different ARDL models were estimated.

From the above equation, the following hypotheses were set to determine whether the employed variables co-integrate.

- The null hypothesis $\left(\mathrm{H}_{0}\right)$ for no co-integration: $\varphi_{1}=\varphi_{2}=0$

- The alternative hypothesis $\left(\mathrm{H}_{1}\right)$ for no co-integration: $\varphi_{1} \neq \varphi_{2} \neq 0$

In order to test these hypotheses, the bound test, which is F-test in ARDL model, was employed. This test allows a comparison between estimated F-statistics and critical value from the Pesaran et al. (2001) table. The null hypothesis is rejected if F-statistic is greater than the upper critical value from the table and the conclusion is that a long-run relationship (co-integration) exists between variables. However, if the lower critical value from the table is greater than the calculated F-statistics, the null hypothesis is not rejected and the conclusion is that there is no co-integration between variables. Without further information, the outcome is inconclusive if the estimated F-value lies between the upper and lower critical values (Dube \& Zhou, 2013). The result from co-integration determines if the study can proceed with error correction model (ECM). If there is a presence of long-run relationships between variables, then the following ECM equation is derived from Equation:

$\Delta E M P_{t}=\propto_{1}+\sum_{j=1}^{k} \beta_{1 j} \Delta E M P_{t-j}+\sum_{j=1}^{k} \lambda_{1 j} \Delta G O V S_{t-j}+\delta u_{t-1}+e_{t}$

Whereas $\mathrm{u}_{\mathrm{t}-1}$ symbolises the error correction term and $\delta$ is its coefficient, which measures the speed of adjustment towards the long-run equilibrium.

Prior to the ARDL estimation, the correlation analysis test was performed in order to establish the relationship between variables. The Schwarz' Bayesian information criterion was used to determine the optimal number of lags to be employed by the study. The choice was made because this criterion provides accurate results regardless of the sample size of the data (Brooks, 2014). Furthermore, to ensure the accuracy of the obtained results, certain diagnostic tests such as normality, stability, autocorrelation and heteroscedasticity were performed and the study passed all the tests. 


\section{Empirical Findings}

Correlation Analysis: Correlation coefficient ( $\mathrm{r}$ ) is a measurement of the statistical relationship between two variables. It lies between -1 and +1 . Mathematically, it is presented as follow: $-1 \leq r \leq 1$. The closer to zero the correlation coefficient, the smaller the relationship between the two variables and the further from zero the relationship is between those variable (Ahlgren et al., 2003). In other words, the higher the absolute value the stronger the association between the variables. The correlation between LGOVS and other variables (LECONS, LEFIN, LERET, and LEMAN) is significant at the 5 percent level of significance. However, the correlation between LGOVS and LEMIN is not significant. These results suggest a strong association between government spending and employment in retail, construction, financial and manufacturing sectors. In addition, a positive correlation between LGOVS and other variables is observed except LERET and LEMAN, which have a negative association with LGOVS. The correlation coefficients among sectors are all significant at 1 percent level of significance, excluding the correlation coefficient between LEMIN and LEFIN. There is a negative and weak correlation between LECON and LERET, a strong and positive correlation between LEFIN and LECONS, a strong and negative correlation between LEFIN and LERET. The correlation of LEMAN with other sectors is negative, except its correlation with LERET. Lastly, the correlation between LEMIN and other sectors seems to be weaker compared to other sectors' correlations.

Table 1: Pearson's Correlation Coefficients

\begin{tabular}{lllllll}
\hline & LGOVS & LERET & LECONS & LEFIN & LEMAN & LEMIN \\
\hline LGOVS & 1 & & & & & \\
LERET & $-0.727^{*}$ & 1 & & & & \\
LECON & $0.786^{*}$ & -0.500 & 1 & & & \\
LEFIN & $0.906^{*}$ & -0.882 & 0.808 & 1 & & \\
LEMAN & $-0.812^{*}$ & 0.754 & -0.383 & -0.740 & 1 & \\
LEMIN & $0.073^{*}$ & 0.349 & 0.468 & -0.018 & 0.416 & 1 \\
\hline
\end{tabular}

Note: * indicates significant at the $5 \%$ level of significance

Unit root and ARDL Model Selection: For the ARDL model to be used none of the variables should be I (2); thus, the ADF unit root test was used to test if the variables meet this condition. The ADF results, exhibited in Table 2, show that not all variables are stationary at levels. However, they become stationary at first differences. Therefore, all variables are integrated of order one, that is, they are I (1). This means that the ARDL model can be used to test for the co-integration between the variables.

Table 2: Augmented Dickey-Fuller Unity Root Test

\begin{tabular}{|c|c|c|c|c|c|c|c|}
\hline \multirow[t]{2}{*}{ Variables } & \multirow{2}{*}{$\begin{array}{l}\text { Level } \\
\text { intercept } \\
\text { t-Stat. }\end{array}$} & \multirow[b]{2}{*}{ P-values } & \multicolumn{2}{|c|}{ Trend \&intercept } & \multicolumn{2}{|c|}{ First difference } & \multirow[t]{2}{*}{$\begin{array}{c}\text { Integration } \\
\text { order }\end{array}$} \\
\hline & & & t-Stat. & P-values & t-Stat. & P-values & \\
\hline LGOVS & -2.8955 & 0.9595 & -3.4635 & 0.0982 & -2.8959 & $0.0086^{* *}$ & $\mathrm{I}(1)$ \\
\hline LERET & -2.8951 & 0.3701 & -3.4622 & 0.9919 & -2.8963 & $0.0139 *$ & $\mathrm{I}(1)$ \\
\hline LECON & -2.8951 & 0.7514 & -3.4622 & 0.5486 & -2.8955 & $0.0000^{* *}$ & $\mathrm{I}(1)$ \\
\hline LEFIN & -2.8951 & 0.7136 & -3.4622 & 0.6975 & -2.8955 & $0.0000^{* *}$ & $\mathrm{I}(1)$ \\
\hline LEMAN & -2.8951 & 0.5818 & -3.4622 & 0.5595 & -2.8955 & $0.0000^{* *}$ & $\mathrm{I}(1)$ \\
\hline LEMIN & -2.8955 & 0.2017 & -3.4629 & 0.5056 & -2.8955 & $0.0001^{* *}$ & $\mathrm{I}(1)$ \\
\hline
\end{tabular}

** denotes the rejection of the null hypothesis of unit root at the $1 \%$ significance level

* denotes the rejection of the null hypothesis of unit root at the $5 \%$ significance level 
Table 3: ARDL Model Selection

\begin{tabular}{llllll}
\hline & Model 1 & Model 2 & Model 3 & Model 4 & Model 5 \\
\cline { 2 - 6 } Variables & LERET \& & LECON \& & LEFIN \& & LEMAN \& & LEMIN \& \\
& LGOVS & LGOVS & LGOVS & LGOVS & LGOVS \\
Selected model & ARDL 3,0 & ARDL 0,0 & ARDL 1,0 & ARDL 1,2 & ARDL 1,0 \\
\hline
\end{tabular}

Table 3 presents the outcome of the model specification for each sector. The best model was selected by EViews 9 with SBIC information criterion. The maximum number of four lags suggested initially for independent and dependent variables in each of the five models. With regard to the model selection, the best model between employment in retail sector and total government spending was ARDL $(3,0)$ whilst ARDL $(0$, 0 ) was the best model between employment in construction, financial sector and government spending. Lastly, ARDL $(1,2)$ and ARDL $(1,0)$ were selected for employment in manufacturing, mining and total government spending, respectively.

Analysis of Long-run Relationships: Having selected the best ARDL model for each economic sector, the next step was to determine whether there is a long-run relationship between government spending and employment in each sector. Table 4 shows the estimated F-statistics and their corresponding lower and upper values with unrestricted intercept without trend (Pesaran et al., 2001). The estimated F-values of retail, construction, financial, manufacturing and mining are 4.47; 3.44; $1.09 ; 3.92$ and 7.93 respectively. These results show that all estimated F-values are less than the lower bound of 6.56 at the 5 percent level of significance. Therefore, the null hypothesis of non-co-integration between job creation in these four sectors, namely retail, construction, financial, manufacturing and government spending was not rejected. This signals the lack of long-run relationship between government spending and job creation in these sectors. The F-value of employment in mining sector (7.93) is greater than upper bound value of 7.3, implying that the null hypothesis for non-co-integration is rejected. This implies that the co-interacting relationship between government spending and employment is significant only in the mining sector. Thus, in the long-run, government spending creates jobs in the mining sector but not in the other four sectors.

Table 4: Bound Test for Co-integration

\begin{tabular}{lllll}
\hline & $\begin{array}{l}\text { Estimate } \\
\text { d F-value }\end{array}$ & \multicolumn{2}{l}{ Pesaran critical value at 5\% } & Presence of \\
Model & & Lower bound & Upper bound & co-integration \\
\hline ARDL(2,0): retail & 4.47 & 6.56 & 7.3 & No \\
ARDL(1,0): construction & 3.44 & 6.56 & 7.3 & No \\
ARDL(1,0): financial & 1.09 & 6.56 & 7.3 & No \\
ARDL1,0): manufacturing & 3.92 & 6.56 & 7.3 & No \\
ARDL(2,0): mining & 7.93 & 6.56 & 7.3 & Yes \\
\hline
\end{tabular}

Note: The unrestricted intercept without trend table was utilised for critical values (Pesaran et al., 2001).

The co-integration results are in line with other studies (Afonso \& Sousa, 2009; Ramey, 2012; Beard et al., 2011;World Bank, 2013; Kerr et al., 2014; Mahmood \& Khalid, 2013; OECD, 2015) that found government spending might not create or stimulate jobs within the private sector due to economic variability of the economic cycle. However, the long-run relationship between government spending and job creation in the mining sector is supported by the studies by Dlamini, (2012), Maia, (2013) and Houseman, (2014) whose findings asserted a positive relationship between government spending and job creation in the mining sector. The long-run equation ${ }^{1}$ for the mining sector shows that a 1 percent increase in government spending increases job creation in the mining sector by 0.25 percent. Consequently, increasing government spending leads to the long-run increases in the number of people employed in the mining sector.

Analysis of Short-run Relationships: After testing for the long-run relationship, the next step was to estimate the error correction model (ECM) to determine the speed of adjustment towards the long-run

1The long-run equation can be abstained from corresponding author. 
equilibrium. The outcome of ECM estimation is exhibited in Table 6. The presence of a negative sign for error correction term, which is significant at the 5 percent level of significance, implies that the model restores the equilibrium. The coefficient of -0.035721 indicates that around 3.6 percent of any disequilibrium between employment in the mining sector and government spending is corrected each quarter. This means that it takes approximately $28(1 / 0.035721)$ quarters for changes in government spending to have a complete effect on job creation in the mining sector. Therefore, about seven years are required for government spending to completely create employment in the mining sector. In the ECM, the coefficient for changes in government spending is not significant, suggesting that government spending does not have a short-run effect on job creation in the mining sector. The coefficient for lag one of mining employment is significant at the 1 percent level of significance, suggesting that current employment in the mining sector is affected by the employment created in the previous quarter.

Since there is only a long-run relationship between government spending and the mining sector, the shortrun relationships were estimated to determine whether government spending could at least create shortterm jobs in the other four sectors. The short-run results for non-co-integrated variables are depicted in Table 6. These results show that in the remaining four sectors, namely retail, construction, financial and manufacturing, employment in previous quarter affects current employment. However, government spending does not have any short-term effect on job creation in the financial and retail sectors. This confirms the finding from previous studies (Haltiwanger et al., 2010; Kerr et al., 2014) that new and starting businesses may destroy more jobs than they create. Moreover, if government spending stimulates the financial sector, which increases funding for the use of advanced technology, more jobs will be lost than created. Nonetheless, the null hypothesis suggesting that there is no short-run relationship between government spending and job creation in construction and manufacturing sectors was rejected in favour of the alternative. Therefore, government spending creates only short-term jobs in construction and manufacturing sectors. These findings suggest that the sum of money spent by government on construction and subsidies for domestic manufactured products tends to boost short-term employment in construction and manufacturing sectors (Girma et al., 2007; Beard et al., 2011; Boushey \& Ettlinger, 2011; Dlamini, 2012; Maia, 2013). Thus, government spending can assist in creating short-term jobs in most of the South African economic sectors.

Table 5: ECM Results for the Mining Sector

\begin{tabular}{lllll}
\hline Variable & \multicolumn{1}{c}{ Coefficient } & Std. Error & t-Statistic & Prob. \\
\hline D(LMIN(-1)) & 0.530268 & 0.091586 & 5.789826 & 0.0000 \\
D(LGOVS) & -0.008423 & 0.165288 & -0.05096 & 0.9595 \\
ECT(-1) & -0.035721 & 0.016695 & -2.13963 & 0.0353 \\
\hline
\end{tabular}

Table 6: Short-run Results for the Four Non-co-integrating Sectors

\begin{tabular}{llllll}
\hline Model & Variable & Coefficient & Std. Error & t-Statistic & Prob. \\
\hline & D(LERET (-1)) & -0.09642 & 0.114412 & -0.84275 & 0.402 \\
& D(LERET (-2)) & 0.193863 & 0.111087 & 1.745145 & 0.253 \\
LERET vs. LEGOVS & D(LERET (-3)) & 0.292604 & 0.109443 & 2.673582 & 0.0462 \\
& D(LGOVS) & 0.119215 & 0.42986 & 0.277335 & 0.3527 \\
& C & -0.00477 & 0.004702 & -1.01494 & 0.3133 \\
\hline & D(LECONS) & 0.0721 & 0.109376 & 0.659193 & 0.5116 \\
& D(LGOVS) & 0.1235 & 0.053309 & 2.316667 & 0.023 \\
LECONS vs. LGOVS & C & -0.00274 & 0.009476 & -0.28955 & 0.7729 \\
\hline \multirow{3}{*}{ LEFIN vs. LGOVS } & LEFIN(-1) & 0.926041 & 0.050135 & 18.47099 & 0.000 \\
& LGOVS & 0.263347 & 0.234423 & 1.123382 & 0.2645 \\
& C & -3.12271 & 2.879523 & -1.08446 & 0.2813 \\
\hline & LEMAN(-1) & 0.928517 & 0.037611 & 24.68764 & 0.000 \\
LEMAN vs. LGOVS & LGOVS & -0.65493 & 0.27853 & -2.35137 & 0.0211 \\
& LGOVS(-1) & 1.136311 & 0.51052 & 2.225792 & 0.0288 \\
& LGOVS(-2) & -0.49893 & 0.280259 & -1.78026 & 0.0788 \\
& C & 0.56093 & 0.339649 & 1.6515 & 0.1025 \\
\hline
\end{tabular}


Diagnostic Tests Results: To ensure the accuracy of the study findings, we conducted a number of diagnostic tests $^{2}$. Results from these tests as certain that there is no evidence of heteroscedasticity, serial correlation and that residuals are distributed normally. The test for parameter stability also showed that parameters were stable. Thus, the estimate five ARDL models met the required econometric assumptions.

\section{Conclusion and Recommendations}

In this study, the effects of government spending on job creation in five major economic sectors in South Africa were explored. The expectation was that government spending creates, or at least stimulates, employment in different economic sectors as suggested by the literature. However, the results found no evidence supporting long-run relationships between government spending and employment in retail, construction, financial and manufacturing sectors. Government spending can only create long-term employment in the mining sector. This implies that the South African government should spend more on the mining sector than other sectors in order to create durable jobs. Short-run findings indicated government spending creates jobs in construction and manufacturing sectors. This means that government spending can assist in creating temporary jobs in construction and manufacturing sectors but such short-term employment would not lead to a permanent solution for the challenge of the high unemployment rate in South Africa. The South African government should consider job creation as one of its major priorities as job creation is considered to be an engine that generates economic growth and leads to a better standard of living. Although government might be spending more resources on employment creation, the results from this study show that the long-term effect of spending by government is minimal, even insignificant, in most sectors considered in this study. Therefore, it would be better if government officials and macroeconomic policy makers revise their spending strategies. Increased government spending on mining sector is therefore encouraged. Given that government spending encompasses two main components, namely consumption spending and investment spending, the South African government should focus more on investment spending to improve employment creation, as consumption spending does not create durable jobs. However, the role of consumption spending in creating short-term jobs, that can help people to survive while waiting for durable jobs, should also be considered.

\section{References}

Afonso, A. \& Sousa, R. M. (2012). The macroeconomic effects of fiscal policy. Applied Economics, 44(34), 44394454.

African Economic Outlook. (2015). Regional development and spatial inclusion. http://dx.doi.org/10.1787/aeo-2015-en pdf. Date of access: 21 June2016.

Ahlgren, P., Jarneving, B. \& Rousseau, R. (2003). Requirements for a cocitation similarity measure, with special reference to Pearson's correlation coefficient. Journal of the American Society for Information Science and Technology, 54(6), 550-560.

Asmundson, I. (2011). Back to basics: what are financial services? https://www.imf.org/external/pubs/ft/fandd/2011/03/pdf/basics.pdf, Date of access: 11March.2016.

Atkinson, A. B. \& Stiglitz, J. E. (2015). Lectures on public economics. Princeton University Press.

Beard, T. R., Ford, G. S., Kim, H. \& Spiwak, L. J. (2011). Can government spending get America working again? An empirical investigation. Phoenix Center Policy Bulletin, 31, 1-15.

Bertolis, D. E. \& Hayes, M. (2014). An investigation into South African general equity unit trust performance during different economic periods. South African actuarial journal, 14, 73-99.

Botha, R. (2015). Economic outlook. In navigating a volatile landscape: Major Banks analysis -South Africa. https://www.pwc.co.za/en/assets/pdf/bank-analysis-march-2015.pdf. Date of access: 11 March.2016.

Boushey, H. \& Ettlinger, M. (2011). Government spending can create jobs and it has. Center for American progress.https://cdn.americanprogress.org/wpcontent/uploads/issues/2011/09/pdf/yes_we_can.p df. Date of access 17 July. 2016.

Brooks, C. (2014). Introductory econometrics for finance 3rd Ed. Cambridge University Press.

${ }^{2}$ Results of the diagnostic tests can be obtained from the corresponding author. 
Cogan, J. F., Cwik, T., Taylor, J. B. \& Wieland, V. (2010). New Keynesian versus old Keynesian government spending multipliers. Journal of Economic dynamics and control, 34(3), 281-295.

Cray, A., Nguyen, T., Pranka, C., Schildt, C., Sheu, J. \& Whitcomb, E. R. (2011). Job Creation: A review of policies and strategies. IRLE working paper, 11(105), 1-57.

Dlamini, S. (2012). Relationship of construction sector to economic growth. In International Congress on Construction Management. Canada.

Dornbusch, R., Fischer, S. \& Startz, R. (2014). Macroeconomics, New York: McGraw-Hill Education.

Dube, S. \& Zhou, Y. (2013). South Africa's short term and long term interest iates: A threshold cointegration analysis. Business and Economic Research, 3(1), 187-211.

Edelberg, W., Eichenbaum, M. \& Fisher, J. D. M. (2002). Understanding the effects of a shock to government purchases. Review of Economic Dynamics, 2, 166-206.

Estache, A., Perrault, J. F. \& Savard, L. (2012). The impact of infrastructure spending in Sub-Saharan Africa: a CGE Modelling Approach. Policy Research Working Paper Series 5386. Washington, DC: The World Bank.

Farmer, R. E. (2010). How to reduce unemployment: A new policy proposal. Journal of Monetary Economics, 57(5), 557-572.

Ferreira, L. \& Rossouw, R. (2016). South Africa's economic policies on unemployment: a historical analysis of two decades of transition. Journal of Economic and Financial Sciences, 9(3): 807-832.

Girma, S., Görg, H., Strobl, E. \& Walsh, F. (2007). Creating jobs through public subsidies: An empirical analysis. IZA Discussion Paper, no. 3168.

Habanabakize, T. \& Muzindutsi, P. F. (2015). Time series analysis of interaction between aggregate expenditure and job creation in South Africa. Journal of Governance and Regulation, 4(4), 649-657.

Haltiwanger, J., Jarmin, R. \& Miranda, J. (2010). Who creates jobs? Small vs. large vs. young. NBER Working Paper 16300. National Bureau of Economic Research, Cambridge, MA.

Hassen, E. K. (2000). Infrastructure delivery and employment creation in South Africa: In TIPS Conference 2000 Annual Forum.Glenburn Lodge: Trade and industrial policy secretariat.

Holden, S. \& Sparrman, V. (2016). Do government purchases affect unemployment? University of Oslo. Retrieved from http://folk.uio.no/sholden/wp/fiscal-U.pdf, Date of access 11April. 2016.

Houseman, S. N. (2014). The role of manufacturing in a jobs recovery. Washington, D.C: Center on Budget and Policy Priorities.

International Labour Conference (ILC). (2015). Small and medium-sized enterprises and decent and productive employment creation. Report IV. Geneva: International Labour Office.

International Labour Organization. (2009). World employment and social outlook. http://www.ilo.org/wcmsp5/groups/public/---dgreports/---dcomm/--publ/documents/publication/wcms_337069.pdf, Date of Access: 17July.2016.

Johansen, S. \& Juselius, K. (1990). Maximum Likelihood estimation and inference on cointegration with applications to the demand for money. Oxford Bulletin of Economics and Statistics, 52(2), 169-210.

Kenyon, P. (1997). Infrastructure spending and unemployment: government responsibility for growth and jobs. Australian Economic Review, 30(4), 421-32.

Kerr, A., Wittenberg, M. \& Arrow, J. (2014). Job creation and destruction in South Africa. South African Journal of Economics, 82, 1-30.

Kingdon, G. G. \& Knight, J. (2004). Unemployment in South Africa: The nature of the beast. World Development, 32(3), 391-408.

Leigh, A. \& Neill, C. (2011). Can national infrastructure spending reduce local unemployment? Evidence from an Australian roads program. Economics Letters, 113(2), 150-153.

Levine, L. (2009). Job loss and infrastructure job creation during the recession. Congressional Research Service, Cornell University ILR School. Federal Publications.

Loizides, J. \& Vamvoukas, G. (2005). Government expenditure and economic growth: evidence from trivariate causality testing. Journal of Applied Economics, 8(1), 125-152.

Mabugu, R. E. (2016). Responding to South Africa's infrastructure challenge. file://C:/Users/NWUUser/Downloads/Pages\%20from\%20SUBMISSION\%202016_2017\%20Chapte r\%201.pdf. Date of access: 11August.2016.

Mahmood, H. \& Khalid, S. (2013). Fiscal Policy for growth and employment generation in Pakistan. Academic Research International, 4(6), 372-381. 
Maia, J. (2013). The interface between mining and manufacturing sectors in South Africa. Industrial Development Corporation. Department of Research and Information.

Maisonnave, H., Mabugu, R., Chitiga, M. \& Robichaud, V. (2013). Analysing job Creation effects of scaling up infrastructure spending in South Africa. Cahier de recherche/Working paper, 10(13), 1-28.

Meyer, D. F. (2014). Job creation, a mission impossible? The South African case. Mediterranean Journal of Social Sciences, 5(16), 65-77.

Muzindutsi P. F. \& Maepa M. M. (2014) Manufacturing Production and Non-Agricultural Employment rate in South Africa: Time Series Analysis. Journal of Economics and Behavioral Studies, 6(10), 779-786.

Neumark, D. (2011). Policies to encourage job creation: hiring credits vs. worker subsidies. Cambridge: National Bureau of Economic Research.

OECD. (2015). New evidence on the role of young firms in creating jobs. http://www.oecd.org/sti/youngSME-growth-and-job-creation.pdf, Date of access: 14. 03. 2016.

Padayachee, A. \& Desai, A. (2011). Post-Apartheid South Africa and the crisis of expectation-DPRN Fourhttp://rozenbergquarterly.com/post-apartheid-south-africa-and-the-crisis-of-expectationdprn-four/.Date of access 16 June. 2016.

Pesaran, M. H. \& Shin, Y. (1995). Long-run structural modelling. Department of Applied Economics, Cambridge: University of Cambridge.

Pesaran, M. H. \& Shin, Y. (1996). Cointegration and speed of convergence to equilibrium. Journal of econometrics, 71(1), 117-143.

Pesaran, M. H., Shin, Y. \& Smith, R. J. (2001). Bounds testing approaches to the analysis of level relationships. Journal of Applied Econometrics, 16(3), 289-326.

Praveen, M. V. (2011). Financial services. School of distance education. University of Calicut.

Ramey, V. A. (2012). Government spending and private activity. NBER, San Diego: University of California.

Ranchhod, V. \& Finn, A. (2016). Estimating the short-run Effects of South Africa's Employment Tax Incentive on youth employment probabilities using a difference-in-differences approach. South African Journal of Economics, 84(2), 199-216.

Riedl, B. (2008). Why government spending does not stimulate economic growth. The Heritage Foundation.http://www.heritage.org/research/reports/2008/11/why-government-spending-doesnot-stimulate-economic-growth. Date of access: 15 November.2016.

Roberts, R. (2010). Does government spending create jobs? http://cafehayek.com/2010/10/doesgovernment-spending-create-jobs.htmlDate of access: 16 September 2016.

Saks, R. E. (2008). Job creation and housing construction: Constraints on metropolitan area employment growth. Journal of Urban Economics, 64(1), 178-195.

Statistics South Africa (StatsSA). (2015). Quarterly Labour Force Survey. Pretoria.

South African Reserve Bank (SARB). (2015). Full Quarterly Bulletin. December 2015, no. 278. Pretoria.

StatsSA see Statistics South Africa.

South African Revenue Services (2016). Employment tax incentive (ETI). http://www.sars.gov.za/TaxTypes/PAYE/ETI/Pages/default.aspx.Date of access: 15 August 2016.

Tcherneva, P. R. (2008). Keynes's approach to full employment: aggregate or targeted demand?

Wessels, J. \& Ellis, W. (2012). Are SMEs the answer for job creators? Towards the operationalization of a SME Observatory. Paper presented at Towards Carnegie III at the University of Cape Town from3 to7 September 2012.

World Bank. (2013). Jobs, a world development report. Washington, DC. World Bank. 